\title{
CONCRETE BASED ON ALKALI ACTIVATED FLY ASH FROM ONE POWER PLANT IN SERBIA
}

\author{
Dragas Jelena ${ }^{1}$, Marinkovic Snezana ${ }^{2}$, Ignjatovic $\operatorname{Ivan}^{3}$, Tosic Nikola ${ }^{4}$ \\ ${ }^{1}$ MSc, Department of Materials and Structures, University of Belgrade, Faculty of Civil Engineering, Belgrade, Serbia \\ ${ }^{2}$ PhD, Department of Materials and Structures, University of Belgrade, Faculty of Civil Engineering, Belgrade, Serbia \\ ${ }^{3}$ PhD, Department of Materials and Structures, University of Belgrade, Faculty of Civil Engineering, Belgrade, Serbia \\ ${ }^{4}$ MSc, Department of Materials and Structures, University of Belgrade, Faculty of Civil Engineering, Belgrade, Serbia
}

\begin{abstract}
Alkali activated fly ash concrete (AAFAC) prepared with a class F fly ash from power plant „Nikola Tesla B“ and a mixed alkali activator of sodium silicate and sodium hydroxide solutions was investigated. Firstly, eight alkali activated fly ash pastes (AAFAP) with different activator concentration were tested in order to investigate the effect of this concentration on the compressive strength and workability. These pastes were prepared with different mass ratios of sodium silicate and sodium hydroxide solutions and a mass ratio of total alkali activator to fly ash equal to 0.6. Analyzing the compressive strength, cost and environmental effect of these mixtures, the mixture made with 10M sodium hydroxide solution, and a mass ratio of sodium silicate to sodium hydroxide equal to 10 was chosen as the optimal one for further analysis on concrete. To analyze the influence of additional water on the slump and compressive strength of AAFAC six different mixtures were made and tested. All samples were cured in the oven at the temperature of $80^{\circ} \mathrm{C}$ for six hours. The results of compressive strength and workability of tested concretes showed that fly ash from power plant "Nikola Tesla B“ can be used as a binder in AAFAC made with sodium silicate and sodium hydroxide as alkali activators.
\end{abstract}

Keywords: Concrete, Fly ash, Alkali activation, Sodium silicate, Sodium hydroxide

\section{INTRODUCTION}

Despite modernization efforts in many countries, the main energy source globally still remains coal combustion. As a result, large amounts of fly ash, a by-product of coal combustion, are being generated worldwide. The U.S. produces roughly 131 million tons of fly ash each year [1], China and India 300 million tons [2]. In Serbia, there are six coal-burning power plants which cover about $70 \%$ of the country's electric energy needs [3]. During 2010, about 40 million tons of coal was exploited and transported from "Kolubara" and "Kostolac" mines. But these processes have a major environmental consequence -6 million tons of fly ash obtained per year, mostly produced in "Nikola Tesla A" and "Nikola Tesla B" power plants located about $30 \mathrm{~km}$ away from Belgrade, the city with 2 million people and the capital of Serbia. In Serbia, about 200 million tons of fly ash is being currently deposited at surface area of 1.500 hectares. Fly ash landfills are located next to power plants and they cover a significant part of the arable land. In power plant "Nikola Tesla B", during the 2009/2010 repair, the new system of collection, transport and disposal of fly ash was established. Applying new technology enabled collecting of dry fly ash in silos and its delivery for the industrial needs afterwards. But, at the moment, only $2.7 \%$ of the total fly ash production in Serbia is used by the construction industry [4].

Human activities represent a serious threat to the environment and among them the building industry has one of the largest environmental impacts. Concrete is the world's most consumed man-made material. Unfortunately, the production of Portland cement, the active ingredient in concrete, generates a significant amount of carbon dioxide $\left(\mathrm{CO}_{2}\right)$. During the production of Portland cement, $\mathrm{CO}_{2}$ is released due to the combustion of carbon-based fuels and the calcination of limestone [5]. For each ton of Portland cement clinker that is produced, approximately one ton of the greenhouse gas $\mathrm{CO} 2$ is released [6]. With cement production reaching nearly 6 billion tons per year worldwide, the sustainability of concrete is a very real concern. A reduction in $\mathrm{CO}_{2}$ emissions may be achieved by reducing the demand for Portland cement with the use of pozzolanic materials in concrete, as a partial replacement of cement. An important achievement is the development of high volume fly ash concrete (HVFAC) that uses approximately $50 \%$ of Portland cement, and yet possesses excellent mechanical properties with enhanced durability performance.

In addition to the environmental impacts of material production and procurement, there are environmental and economic impacts associated with the durability of older concrete infrastructure components. The typical concrete structure is usually designed for a service life of 50 years. However, most structures in urban environment begin to show deterioration after 20-30 years, or earlier [7]. Increasing the service life of structures preserves the natural resources used in concrete manufacturing. 
Potential solution for these problems is the development of inorganic alumino-silicate polymer, called geopolymer, synthesized from materials of geological origin or byproduct materials such as fly ash, that are rich in silicon and aluminum. The geopolymer paste can be used as a binder to produce concrete, instead of the cement paste. Eliminating the cement from the binder, the environmental impact of AAFAC is lower than Portland cement concrete. Beside this benefit, AAFAC posses better durability properties compared to Portland cement concrete. Carbonation of alkali activated binders in service appears to be acceptably slow and alkali aggregate reactions in alkali activated binders seem to be restricted [8]. It has been shown that geopolymer cements possess excellent resistance to sulfates and various acids. The deterioration of Portland cement from sulfate attack is attributed to the formation of expansive gypsum and ettringite which causes cracking and spalling in the concrete [9]. The superior performance of geopolymeric materials in acidic environments is attributed to the lower calcium content of the source material [10].

\subsection{Alkali Activated Fly Ash Concrete (AAFAC)}

Alkali activated binders have attracted much interest in academic and commercial spheres over the past decade or more. Research done in this field until today show a great potential for use of geopolymer concrete in construction industry. The name 'geopolymer' was introduced by Davidovits in the 1970s [11], but the technology of alkaliactivation predates this terminology by more than 60 years, with a patent awarded to Kuhl in 1908 [12], research and commercial work conducted in Belgium by Purdon from the 1930s-1950s [13, 14], and an extensive program of research, development and commercial-scale production growing from the work of Glukhovsky in Kiev from the 1950s onwards [15, 16]. More recent commercial development work has led to the larger scale availability, and regulatory standardization of alkali activated concrete in various parts of the world $[8,17,18]$.

AAFAC is most widely used geopolymer concrete type, mainly because of the large quantities of fly ash that are globally generated every year in power plants. Fly ash particles are typically spherical, finer than Portland cement and lime, ranging in diameter from less than $1 \mu \mathrm{m}$ to no more than $150 \mu \mathrm{m}$. The chemical composition is mainly composed of the oxides of silicon $\left(\mathrm{SiO}_{2}\right)$, aluminum $\left(\mathrm{Al}_{2} \mathrm{O}_{3}\right)$, iron $\left(\mathrm{Fe}_{2} \mathrm{O}_{3}\right)$, and calcium $(\mathrm{CaO})$, whereas magnesium, potassium, sodium, and titanium are also present in a lesser amount. The major influence on the fly ash chemical composition comes from the type of coal. ASTM C618 [19] classifies fly ash as Class C or F. It is true that the specification states that Class $\mathrm{F}$ ashes are mainly produced from bituminous or anthracite coals and that Class $\mathrm{C}$ ashes are mainly produced from sub-bituminous or lignite coals, but the main criterion for classification are its chemical requirements: $\mathrm{SiO}_{2}+\mathrm{Al}_{2} \mathrm{O}_{3}+\mathrm{Fe}_{2} \mathrm{O}_{3}>70 \%$ for Class $\mathrm{F}$ and $\mathrm{SiO}_{2}+\mathrm{Al}_{2} \mathrm{O}_{3}+\mathrm{Fe}_{2} \mathrm{O}_{3}>50 \%$ for Class C. Usually, Class $\mathrm{F}$ fly ashes have a low content of $\mathrm{CaO}$ and exhibit pozzolanic properties, and Class $\mathrm{C}$ fly ashes contain more than $12 \%$ of $\mathrm{CaO}$ and exhibit cementitious properties. Fly ash from six power plants in Serbia is classified as class F. Aside from the chemical composition, loss on ignition - LOI (unburnt carbon remaining in the ash), fineness and uniformity are the characteristics of fly ash that are generally considered. Fineness of fly ash mostly depends on the operating conditions of coal crushers and the grinding process of the coal itself. Finer gradation generally results in a more reactive ash.

Activation of fly ash with alkaline solutions enables this byproduct material to be a cement-like construction material. In this case, concrete binder can be produced without using any Portland cement; in other words, the role of Portland cement can be totally replaced by the activated fly ash. Palomo et al. [20] described two different models of the activation of fly ash or other by-product materials. For the first model, the silicon and the calcium in the material is activated by a low to mild concentration of alkaline solution. The main product of the reaction is believed to be a calcium silicate hydrate $(\mathrm{C}-\mathrm{S}-\mathrm{H})$ that results from the hydration process. On the contrary, the material used in the second model contains mostly silicon and aluminum, and is activated by a highly alkaline solution. The chemical process in this case is geopolymerisation.

Geopolymers are a member of the family of inorganic polymers, and are a chain structures formed on a backbone of $\mathrm{Al}$ and $\mathrm{Si}$ ions. The geopolymerisation process involves a substantially fast chemical reaction under highly alkaline condition on $\mathrm{Si}-\mathrm{Al}$ minerals, that results in a three dimensional polymeric chain and ring structure consisting of Si-O-Al-O bonds [21].

Mechanism of setting and hardening of the geopolymer material is not clear, as well as its reaction kinetics. However, most proposed mechanism consist of the following [21, 22]: dissolution of $\mathrm{Si}$ and $\mathrm{Al}$ atoms from the source material through the action of hydroxide ions, transportation or orientation or condensation of precursor ions into monomers and setting or polymerisation of monomers into polymeric structures. These three steps can overlap with each other and occur almost simultaneously, thus making it difficult to isolate and examine each of them separately [23]. Davidovits [21] proposed the possible applications of the geopolymer material depending on the molar ratio of $\mathrm{Si}$ to $\mathrm{Al}$, recommending the use of fly ash with this molar ratio equal to 2 for low $\mathrm{CO}_{2}$ cements, concrete and radioactive and toxic waste encapsulation. Fly ash that has molar ratio of $\mathrm{Si}$ to $\mathrm{Al}$ equal to 3 he proposed for the heat resistance composites, foundry equipments and fiber glass composites.

The most common alkaline activator used in geopolymerisation is a combination of sodium hydroxide or potassium hydroxide and sodium silicate or potassium silicate [21]. Palomo et al. [23] concluded that the type of activator plays an important role in the geopolymerisation process. Furthermore, after a study of the geopolymerisation of sixteen natural Al-Si minerals, they found that generally 
the $\mathrm{NaOH}$ solution caused a higher extent of dissolution of minerals than the $\mathrm{KOH}$ solution.

\subsection{Factors Affecting the Properties of AAFAC}

Many researches has shown that physical and mechanical characteristics of AAFAC are influenced by many factors: fly ash particle size and chemical composition, LOI of fly ash, type and concentration of alkali activators $\left(\mathrm{Na}_{2} \mathrm{O}\right.$ concentration and $\mathrm{SiO}_{2} / \mathrm{Na}_{2} \mathrm{O}$ ratio), temperature and duration of curing [24, 25, 26, 27].

Fly ash particle distribution is a very important factor. In order to achieve optimal physical and mechanical characteristics of AAFAC, fly ash should have more than $80-90 \%$ of particles smaller size than $45 \mu \mathrm{m}$ [28]. As stated above, molar ratio of $\mathrm{Si}$ to $\mathrm{Al}$ oxides in fly ash should be around 2. LOI is also a factor of influence, and recommended amount of unburnt coal in fly ash should be less than $5 \%[28]$.

$\mathrm{Xu}$ and van Deventer [22] reported that factors such as the percentage of $\mathrm{CaO}$ and the molar $\mathrm{Si}$ to $\mathrm{Al}$ ratio in the source material significantly influenced the compressive strength of geopolymers. The role and importance of $\mathrm{CaO}$ content in fly ash has been discussed by many researchers [29, 30, 31], and it can be concluded that simply comparing the $\mathrm{CaO}$ content in fly ashes cannot give a clear prediction on the influence on strength of AAFAC. Some of the literature reports low $\mathrm{CaO}$ ashes show higher strength development [29, 30], while other report the opposite [31]. The results obtained by analysis of the hydrated AAFAP indicate that a high content of vitreous phase and low calcium content are important factors determining the reactivity and the performance of fly ashes in alkali activated systems [30].

Type of alkali activator solution is also an important factor influencing the mechanical properties of AAFAC. Both the workability and the strength of the concrete mixture are dependent on the type and concentration of the activator solution. Depending on the type of fly ash, a proper activator should be found. As mentioned before, a silicate and hydroxide solutions are often mixed to form the activator solution.

$\mathrm{Xu}$ and van Deventer [22] confirmed that the addition of sodium silicate solution to the sodium hydroxide solution as the activator enhanced the reaction between the source material and the solution. Palomo et al. [23] confirmed that activator solution that contained soluble silicates was proved to increase the rate of reaction compared to alkaline solutions that contained only hydroxide. The effect of the ratio of sodium silicate to sodium hydroxide on compressive strength and workability was examined in various studies $[32,33,34]$. The addition of sodium silicate to sodium hydroxide activator solution resulted in an increase in strength but a decrease in workability. The mixture became thick and sticky because of the density of the sodium silicate [32].
In addition to the type and ratio of activators, the molarity of the sodium hydroxide solution is also important. As the molarity of the sodium hydroxide solution increases there is an increase in strength and a decrease in porosity [33]. Hardjito [34] concluded that higher ratio of sodium silicate to sodium hydroxide by mass causes higher compressive strength of AAFAC.

Similar to Portland cement, geopolymerisation is more easily achieved with the addition of an external heat source to promote alkaline reactivity of the pozzolanic material. There is a challenge in synthesizing fly ash based geopolymers at ambient temperatures, as others have found that geopolymers did not set at $23{ }^{\circ} \mathrm{C}$ [35].

Research work has demonstrated that curing time and temperature greatly affects the mechanical development of geopolymer binders. Hardjito and Rangan [36] demonstrated that with longer curing time at elevated temperature $\left(60^{\circ} \mathrm{C}\right)$, the compressive strength of AAFAC increased. Similar findings were also reported by Palomo et al. [23], who found that longer curing time under heating resulted in a higher compressive strength. Research also shows that there is a temperature beyond which the strength gain rate is extremely slow [37]. Temperatures in the range of $50-90^{\circ} \mathrm{C}$ are widely accepted values used for successful geopolymer hydration. Both curing temperature and curing time directly influence final compressive strength values of geopolymer specimens. Longer curing time, in the range of 4 to 96 hours, produces higher compressive strength of AAFAC. However, the increase in strength beyond 24 hours is not significant.

\section{EXPERIMENTAL}

In order to analyze the possibilities of fly ash from power plant "Nikola Tesla B" (Obrenovac, Serbia) as a material for the production of AAFAC, paste and concrete specimens prepared with this fly ash and a mix of sodium silicate $\left(\mathrm{Na}_{2} \mathrm{SiO}_{3}\right)$ and sodium hydroxide solution $(\mathrm{NaOH})$ as an activator solution were investigated.

Experimental work was divided in two parts, testing of AAFAP and AAFAC. In order to understand the properties of the binder phase, paste mixtures were tested first.

\subsection{Materials}

In the present experimental work, low calcium Class F fly ash obtained from power plant "Nikola Tesla B" was used as the base material. The chemical composition of the fly ash, determined by X-ray fluorescence (XRF) analysis, is given in Table 1. The molar Si to Al ratio of fly ash is 3.11 and is higher than recommended for application of fly ash in alkali activated fly ash concrete [38, 39]. Also, $\mathrm{CaO}$ content $(10.05 \%)$ is relatively high for Class F. Particle size distribution tests were performed using the Malvern Instruments Mastersizer 2000 and shown in Figure 1. Average mean particle size from three samples of fly ash is $8.533 \mu \mathrm{m}$. Specific gravity of fly ash is $2070 \mathrm{~kg} / \mathrm{m}^{3}$. 
A combination of $\mathrm{Na}_{2} \mathrm{SiO}_{3}$ and $\mathrm{NaOH}$ was chosen as the activator. Sodium silicate solution obtained from GalenikaMagmasil, Serbia was used. The chemical composition of the sodium silicate solution was $\mathrm{Na}_{2} \mathrm{O}=14.7 \%$, $\mathrm{SiO}_{2}=28.08 \%$, and water $57.22 \%$ by mass. Specific gravity of $\mathrm{Na}_{2} \mathrm{SiO}_{3}$ was $1.514 \mathrm{~g} / \mathrm{cm}^{3}$ at $20^{\circ} \mathrm{C}$. Sodium silicate solution $\mathrm{Na}_{2} \mathrm{O} \cdot \mathrm{n} \cdot \mathrm{SiO}_{2}$ had a module $\mathrm{n}=\mathrm{SiO}_{2} / \mathrm{Na}_{2} \mathrm{O}=1.91$.

The $\mathrm{NaOH}$ used in this research was a technical grade sodium hydroxide in pellets, $98 \%$ purity, and obtained from Superlab, Serbia.

Table 1: Chemical composition (\%) of fly ash from power plant "Nikola Tesla B" Obrenovac, Serbia

\begin{tabular}{|l|l|l|l|l|}
\hline $\mathrm{SiO}_{2}$ & $\mathrm{Al}_{2} \mathrm{O}_{3}$ & $\mathrm{Fe}_{2} \mathrm{O}_{3}$ & $\mathrm{CaO}$ & $\mathrm{Na}_{2} \mathrm{O}$ \\
\hline 57.38 & 18.47 & 5.89 & 10.05 & 0.53 \\
\hline $\mathrm{K}_{2} \mathrm{O}$ & $\mathrm{TiO}_{2}$ & $\mathrm{MgO}$ & $\mathrm{P}_{2} \mathrm{O}_{5}$ & $\mathrm{SO}_{3}$ \\
\hline 1.89 & 0.6 & 1.58 & 0.01 & 1.48 \\
\hline $\mathrm{MnO}$ & $\mathrm{LOI}$ & $\mathrm{SiO}_{2} / \mathrm{Al}_{2} \mathrm{O}_{3}$ & $\mathrm{SiO}_{2}+\mathrm{A}_{2} \mathrm{O}_{3}+\mathrm{Fe}_{2} \mathrm{O}_{3}$ \\
\hline 0.03 & 1.65 & 3.11 & 81.74 \\
\hline
\end{tabular}

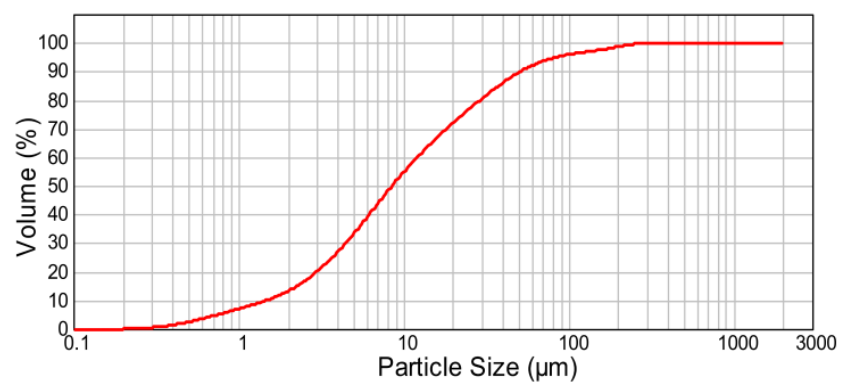

Fig. 1: Particle size distribution of fly ash from power plant "Nikola Tesla B" Obrenovac, Serbia

Table 2: Sieve analysis of aggregates

\begin{tabular}{|l|l|l|l|l|}
\hline $\begin{array}{l}\text { Sieve } \\
\text { size }\end{array}$ & \multicolumn{3}{|l|}{ Percent passing } & \multirow{2}{*}{ Combination* } \\
\cline { 1 - 4 }$(\mathbf{m m})$ & $\mathbf{0 ~ 4}$ & $\mathbf{4 ~ 8}$ & $\mathbf{8} \mathbf{1 6}$ & \\
\hline $\mathbf{0 . 1 2 5}$ & 8.23 & 0.00 & 0.00 & 3.00 \\
\hline $\mathbf{0 . 2 5}$ & 15.65 & 0.00 & 0.00 & 6.00 \\
\hline $\mathbf{0 . 5 0}$ & 30.14 & 0.00 & 0.00 & 12.00 \\
\hline $\mathbf{1}$ & 44.56 & 0.92 & 0.00 & 19.00 \\
\hline $\mathbf{2}$ & 68.37 & 1.45 & 0.32 & 29.00 \\
\hline $\mathbf{4}$ & 98.83 & 16.75 & 1.16 & 44.00 \\
\hline $\mathbf{8}$ & 100.00 & 99.34 & 16.04 & 66.00 \\
\hline $\mathbf{1 6}$ & 100.00 & 100.00 & 100.00 & 100.00 \\
\hline$*) 40.57 \%(16 \mathrm{~mm})+18.50 \%(8 \mathrm{~mm})+40.93 \%$ (sand) \\
\hline
\end{tabular}

Coarse aggregates were obtained in crushed form, majority of the particles were of granite type. For the fine aggregate local river sand was used. Sieve analysis of aggregates and aggregate combination is shown in Table 2.

\subsection{Preparation and Casting of Test Specimens}

To optimize the binder phase properties, a series of AAFAP mixtures were investigated. Eight different pastes mixtures were made in order to determine the effect of concentration of activator solution on the compressive strength.

Two different $\mathrm{NaOH}$ solutions were prepared by dissolving the pellets in distillated water to avoid the effect of unknown impurities in tap water. The mass of $\mathrm{NaOH}$ solids in a solution varied depending on the concentration of the solution expressed in terms of molar, $\mathrm{M}$. $\mathrm{NaOH}$ solution with a concentration of $10 \mathrm{M}$ consisted of $10 \times 40=400$ grams of $\mathrm{NaOH}$ solids (in pellet form) per liter of the solution, where 40 is the molecular weight of $\mathrm{NaOH}$. Other solution, $16 \mathrm{M}$, was made with $16 \times 40=640$ grams of $\mathrm{NaOH}$ pellets per liter of the solution. Specific gravity of $\mathrm{NaOH}$ solutions was: $1.279 \mathrm{~g} / \mathrm{cm}^{3}$ and $1.420 \mathrm{~g} / \mathrm{cm}^{3}$ for $10 \mathrm{M}$ and $16 \mathrm{M}$ solutions respectively.

After dissolving pellets in water, $\mathrm{NaOH}$ was kept in a plastic bottle on a room temperature $\left(20 \pm 2^{\circ} \mathrm{C}\right)$. After cooling down, $\mathrm{NaOH}$ was mixed with $\mathrm{Na}_{2} \mathrm{SiO}_{3}$. In order to determine the influence of $\mathrm{Na}_{2} \mathrm{SiO}_{3}$ and $\mathrm{NaOH}$ mass ratio on the AAFAP compressive strength four different mass ratios were used: $\mathrm{n}=\mathrm{Na}_{2} \mathrm{SiO}_{3} / \mathrm{NaOH}=2,3.5,5$ and 10 .

Activator solution was prepared 24 hours before paste and concrete mixing, and kept on a room temperature in a caped plastic bottle. Measured $\mathrm{pH}$ value of all alkali activated solutions was higher than 14.

Analyzing the results of AAFAP compressive strengths, six different AAFAC mixtures were prepared to evaluate the effect of additional water on the workability and compressive strength of AAFAC.

\subsubsection{Mixing Proportion of AAFAP}

Activator solutions were prepared and mixed with fly ash. The properties of the activation solutions together with mixture proportions are shown in Table 3. Two parameters are chosen to define activator solution used in this research: $\mathrm{Na}_{2} \mathrm{O}$ concentration as a percentage of fly ash mass $\left(\mathrm{Na}_{2} \mathrm{O} / \mathrm{FA}\right)$ and ratio of $\mathrm{SiO}_{2} / \mathrm{Na}_{2} \mathrm{O}$. Eight paste mixtures are made with $\mathrm{Na}_{2} \mathrm{O} / \mathrm{FA}$ ranging from $9.34 \%$ to $12.86 \%$. To conclude what is the effect of soluble $\mathrm{Si}$ in solution, which reacts with dissolved fly ash particles, ratio $\mathrm{SiO}_{2} / \mathrm{Na}_{2} \mathrm{O}$ is chosen in a range from 0.87 to 1.64 .

Table 3: Mixture properties of alkali activated fly ash

\begin{tabular}{|c|c|c|c|c|c|}
\hline & $\begin{array}{l}\mathbf{A A} / \mathbf{F A} \\
(-)\end{array}$ & $\begin{array}{l}\mathrm{NaOH} \\
(\mathrm{M})\end{array}$ & $\begin{array}{l}\mathrm{Na}_{2} \mathrm{SiO}_{3} / \\
\mathrm{NaOH} \\
(-)\end{array}$ & $\begin{array}{l}\mathrm{Na}_{2} \mathrm{O} / \\
\mathbf{F A} \\
(\%)\end{array}$ & $\begin{array}{l}\mathrm{SiO}_{2} / \\
\mathrm{Na}_{2} \mathrm{O} \\
(-)\end{array}$ \\
\hline $1 P$ & \multirow[t]{4}{*}{0.6} & \multirow[t]{4}{*}{10} & 2.0 & 10.72 & 1.04 \\
\hline $2 \mathbf{P}$ & & & 3.5 & 10.09 & 1.30 \\
\hline $3 \mathbf{P}$ & & & 5.0 & 9.77 & 1.44 \\
\hline $4 P$ & & & 10.0 & 9.34 & 1.64 \\
\hline
\end{tabular}




\begin{tabular}{|l|l|l|l|l|}
\hline $\mathbf{5 P}$ & \multirow{2}{*}{$\mathbf{6}$} & 2.0 & 12.86 & 0.87 \\
\cline { 1 - 1 } & & 3.5 & 11.51 & 1.14 \\
\hline $\mathbf{7 P}$ & & 5.0 & 10.84 & 1.30 \\
\hline $\mathbf{8 P}$ & & 10.0 & 9.92 & 1.54 \\
\hline
\end{tabular}

Variation of these parameters was achieved with a combination of $10 \mathrm{M}$ and $16 \mathrm{M} \mathrm{NaOH}$ and $\mathrm{Na}_{2} \mathrm{SiO}_{3}$ solution with different modulus $\mathrm{n}\left(\mathrm{Na}_{2} \mathrm{SiO}_{3} / \mathrm{NaOH}=2,3.5,5\right.$ and 10). All paste samples had alkali activator to fly ash mass ratio of $\mathrm{AA} / \mathrm{FA}=0.6$. This parameter was varied in preliminary study, and ratio of 0.6 was chosen because smaller mass of activator was insufficient to trigger the reaction, i.e. to make an alkali activated fly ash paste.

Preparation of paste samples was carried out according to the Serbian standard SRPS EN196-1 [40], with some necessary modification for preparation of paste samples. For the preparation of pastes fly ash was mixed with the activator solution in a RILEM-CEM mixer. The procedure of mixing was as followed:

1. The entire quantity of activator solution was added to the mixing bowl first. Subsequently, fly ash was added and allowed to rest for 30 seconds.

2. Then the paste was mixed for 30 seconds at low speed $(140 \pm 5 \mathrm{rev} / \mathrm{min})$.

3. Next step is 30 seconds of rest period, which is used to remove the paste from sides of a mixer.

4. The paste was mixed for an additional 90 seconds at medium speed $(285 \pm 10 \mathrm{rev} / \mathrm{min})$.

Cube paste specimens $(40 \times 40 \times 40 \mathrm{~mm})$ were prepared for compressive strength evaluation of AAFAP. Pastes were placed in the molds, vibrated for $2 \times 10$ seconds and then covered in a layer of plastic. To accelerate the process of geopolymerization, samples were cured at $80^{\circ}$ for 6 hours. Once the elevated heating was completed, samples were stored at standard laboratory conditions, $20 \pm 2{ }^{\circ} \mathrm{C}$ and approximately $50 \%$ relative humidity until testing. All samples of AAFAP were tested 48 hours after mixing.

\subsubsection{Mixing Proportion of AAFAC}

The concrete mixtures were designed using a composition of binding phase which gave the best results in the paste testing. Based on the material results obtained for AAFAP, activator solutions containing $\mathrm{NaOH}$ with molarity of $10 \mathrm{M}$ and $16 \mathrm{M}$ were chosen for the evaluation of AAFAC properties. Besides, all mixtures were made with activator solution with modulus of 10 , except for one mixture with modulus equal to 3.5 , Table 4 . To evaluate the influence of additional water on workability and compressive strength of AAFAC, the water content was also varied, Table 4.

Table 4: Mixture proportions of binder phase of AAFAC

\begin{tabular}{|l|l|l|l|l|l|l|}
\hline & $\begin{array}{l}\text { AA/ } \\
\text { FA }\end{array}$ & $\begin{array}{l}\text { LQ/ } \\
\text { FA }\end{array}$ & $\begin{array}{l}\mathbf{N a O H} \\
(\mathbf{M})\end{array}$ & $\begin{array}{l}\mathbf{N a}_{2} \mathrm{SiO}_{3} \\
\mathbf{N a O H} \\
(-)\end{array}$ & $\begin{array}{l}\mathbf{N a}_{2} \mathbf{O} / \\
\mathbf{F A} \\
(\%)\end{array}$ & $\begin{array}{l}\mathbf{S i O}_{2} / \\
\mathbf{N a}_{2} \mathbf{O} \\
(-)\end{array}$ \\
\hline $\mathbf{1}$ & 0.6 & 0.600 & 10 & 10.0 & 9.34 & 1.64 \\
$\mathbf{C}$ & & & & & \\
\hline
\end{tabular}

\begin{tabular}{|c|c|c|c|c|c|}
\hline 2 & 0.625 & & 10.0 & 9.34 & 1.64 \\
\hline 3 & 0.650 & & 10.0 & 9.34 & 1.64 \\
\hline 4 & 0.670 & & 10.0 & 9.34 & 1.64 \\
\hline C & & & & & \\
\hline 5 & 0.600 & \multirow[t]{3}{*}{16} & 10.0 & 9.92 & 1.54 \\
\hline 6 & 0.670 & & 3.5 & 11.51 & 1.14 \\
\hline C & & & & & \\
\hline
\end{tabular}

Additional water was included in total liquid (water and activator solution) to fly ash mass ratio LQ/FA.

The AAFAC mixture design shown in Table 5 consisted of class $F$ fly ash, $\mathrm{Na}_{2} \mathrm{SiO}_{3}, \mathrm{NaOH}$, a blend of coarse aggregates with $\max$ size $16 \mathrm{~mm}$ and $8 \mathrm{~mm}$, and fine aggregate. The aggregate content in the concrete mixture was around $70 \%$ of the total mass. The coarse and fine aggregates in concrete mixtures were saturated surface dry (SSD) to prevent water absorption and addition to the mixture. All concrete mixtures are made with $400 \mathrm{~kg} / \mathrm{m}^{3}$ of fly ash and $240 \mathrm{~kg} / \mathrm{m}^{3}$ of activator solution ( $\left.\mathrm{AA} / \mathrm{FA}=0.6\right)$.

Table 5: AAFAC mixture design

\begin{tabular}{|l|l|l|l|l|l|l|}
\hline & \multicolumn{6}{|l}{ Amount $\mathbf{( k g / \mathbf { m } ^ { \mathbf { 3 } } )}$} \\
\hline & $\mathbf{1 C}$ & $\mathbf{2 C}$ & $\mathbf{3 C}$ & $\mathbf{4 C}$ & $\mathbf{5 C}$ & $\mathbf{6 C}$ \\
\hline $\mathbf{N a O H}$ & 21.8 & 21.8 & 21.8 & 21.8 & 21.8 & 53.3 \\
\hline $\mathbf{N a}_{2} \mathrm{SiO}_{3}$ & 218.2 & 218.2 & 218.2 & 218.2 & 218.2 & 186.7 \\
\hline Fly ash & 400.0 & 400.0 & 400.0 & 400.0 & 400.0 & 400.0 \\
\hline $\begin{array}{l}\text { Coarse } \\
\text { agg. }\end{array}$ & 948.0 & 968.7 & 953.3 & 965.9 & 993.9 & 948.8 \\
\hline Fine agg. & 682.2 & 671.5 & 660.8 & 669.6 & 689.0 & 657.7 \\
\hline Water & 0.0 & 10.0 & 20.0 & 28.00 & 0.0 & 28.0 \\
\hline
\end{tabular}

In the concrete mixture preparation, the first step was adding all dry materials to the mixer in the following order: coarse aggregate, fly ash, and fine aggregate. Dry materials were mixed for 3 minutes. Subsequently, the activator solution was slowly added, and mixed for another 2 minutes. Finally the additional water was added, and mixed for another $90 \pm$ 30 seconds, until ingredients were mixed uniformly. All samples were cast in $100 \times 100 \mathrm{~mm}$ cubes, vibrated for $2 \times 10$ seconds, sealed in a plastic membrane, and cured for 6 hours at $80^{\circ} \mathrm{C}$. The curing conditions were kept the same as for AAFAP. After curing, the samples were removed and stored at laboratory conditions, $20 \pm 2{ }^{\circ} \mathrm{C}$ and approximately $50 \%$ relative humidity until testing. All samples were tested 48 hours after mixing.

\section{RESULTS AND DISCCUSION}

Table 6 shows the results of compressive strength testing of paste and compressive strength and slump of concrete samples. Workability of paste samples wasn't measured, only visual comparison between samples was made. It was concluded that consistency of pastes became stiffer with the increase of $\mathrm{Na}_{2} \mathrm{SiO}_{3}$ in activator solution, and the 
consistency of samples $1 \mathrm{P}$ and $7 \mathrm{P}$ is shown in Figure 2. Increasing the $\mathrm{Na}_{2} \mathrm{SiO}_{3}$ mass in activator and the molarity of $\mathrm{NaOH}$, water content in activator decreases. Similar to the Portland cement pastes, with the decrease of water content in the mixture the consistency became stiffer. Mixture 5P had very short setting time, it hardened during the mixing and the samples were not made.

Figure 4 shows compressive strength of AAFAP samples with $10 \mathrm{M}$ and $16 \mathrm{M} \mathrm{NaOH}$ solution depending on the $\mathrm{Na}_{2} \mathrm{SiO}_{3} / \mathrm{NaOH}$ mass ratio in activator solution. Samples from the mixture $5 \mathrm{P}$ were not tested because the paste hardened during the mixing procedure.

Table 6: Compressive strength of paste samples and slump and compressive strength of concrete samples

\begin{tabular}{|l|l|l|l|l|}
\hline $\begin{array}{l}\text { Paste } \\
\text { samples }\end{array}$ & $\begin{array}{l}\mathbf{f}_{\mathbf{p}, \mathbf{c}} \\
(\mathbf{M P a})\end{array}$ & $\begin{array}{l}\text { Concrete } \\
\text { samples }\end{array}$ & $\begin{array}{l}\mathbf{f}_{\mathbf{p}, \mathbf{c}} \\
(\mathbf{M P a})\end{array}$ & $\begin{array}{l}\text { Slump } \\
(\mathbf{c m})\end{array}$ \\
\hline $\mathbf{1 P}$ & 57.1 & $\mathbf{1 C}$ & 40.7 & 18.3 \\
\hline $\mathbf{2 P}$ & 49.2 & $\mathbf{2 C}$ & 34.3 & 23.3 \\
\hline $\mathbf{3 P}$ & 55.3 & $\mathbf{3 C}$ & 37.2 & 25.3 \\
\hline $\mathbf{4 P}$ & 59.7 & $\mathbf{4 C}$ & 30.5 & 28.0 \\
\hline $\mathbf{5 P}$ & - & $\mathbf{5 C}$ & 43.6 & 13.2 \\
\hline $\mathbf{6 P}$ & 53.9 & $\mathbf{6 C}$ & 36.3 & 26.5 \\
\hline $\mathbf{7 P}$ & 58.8 & & & \\
\hline $\mathbf{8 P}$ & 65.4 & & & \\
\hline
\end{tabular}

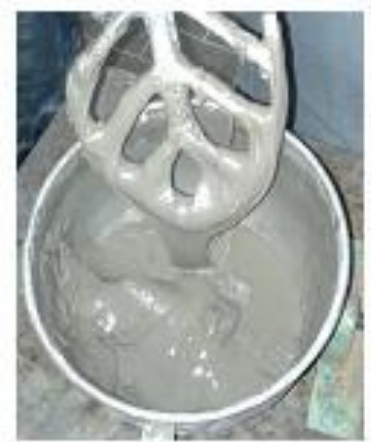

(a)

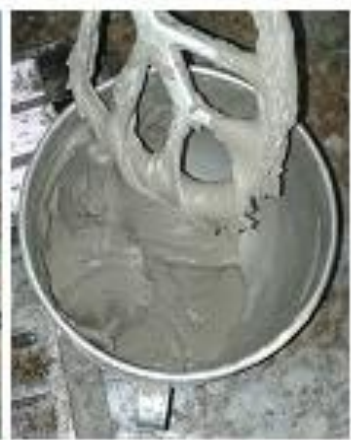

(b)
Fig. 2: Consistency of sample 1P (a) and sample 7P (b)

A few conclusions can be made. It is obvious that AAFAP samples made with higher molarity of $\mathrm{NaOH}(16 \mathrm{M})$ show higher compressive strengths than samples made with $10 \mathrm{M}$ $\mathrm{NaOH}$ for the same $\mathrm{Na}_{2} \mathrm{SiO}_{3}$ content in the activator solution. Figure 3 also shows that with the increase of $\mathrm{Na}_{2} \mathrm{SiO}_{3} / \mathrm{NaOH}$ ratio from 3.5 to 10 the compressive strength increases for both $10 \mathrm{M}$ and $16 \mathrm{M} \mathrm{NaOH}$ mixtures.

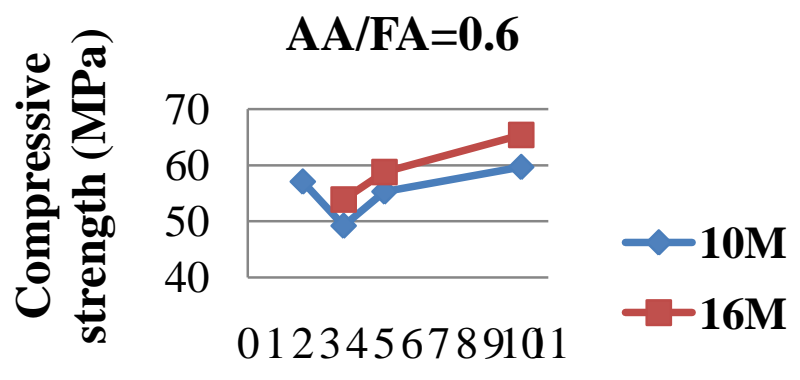

$\mathrm{Na}_{2} \mathrm{SiO}_{3} / \mathrm{NaOH}$

Fig. 3: Compressive strength of AAFAP samples with $10 \mathrm{M}$ and $16 \mathrm{M} \mathrm{NaOH}$ depending on the $\mathrm{Na}_{2} \mathrm{SiO}_{3} / \mathrm{NaOH}$ mass ratio in activator solution

Exception was noticed for mixture $1 \mathrm{P}$ that had $\mathrm{Na}_{2} \mathrm{SiO}_{3} / \mathrm{NaOH}$ ratio equal to 2 and $10 \mathrm{M} \mathrm{NaOH}$. Samples from this mixture had higher compressive strength compared to mixture $2 \mathrm{P}$ and $3 \mathrm{P}$ with higher $\mathrm{Na}_{2} \mathrm{SiO}_{3} / \mathrm{NaOH}$ ratios.

It is not easy to explain the effect of $\mathrm{Na}_{2} \mathrm{SiO}_{3} / \mathrm{NaOH}$ ratio without considering both parameters that are chosen for analysis in this research: the percentage of $\mathrm{Na}_{2} \mathrm{O}$ and $\mathrm{SiO}_{2} /$ $\mathrm{Na}_{2} \mathrm{O}$ in activator. Figure 4 shows the influence of the $\mathrm{Na}_{2} \mathrm{O}$ content on the compressive strength of AAFAP samples. General trend cannot be detected since the samples had different $\mathrm{SiO}_{2}$ content in activator solution. Figure 5 shows the influence of $\mathrm{Si}_{2} \mathrm{O} / \mathrm{Na}_{2} \mathrm{O}$ ratio on the compressive strength of AAFAP samples. Results shown in Figure 5 are for samples with different $\mathrm{Na}_{2} \mathrm{O} / \mathrm{FA}$ percentages. However, analyzing the compressive strength of samples $2 \mathrm{P}, 3 \mathrm{P}$ and $8 \mathrm{P}$ with similar $\mathrm{Na}_{2} \mathrm{O} / \mathrm{FA}$ percentage from 9.77 to 10.09 it is observed that with the increase of $\mathrm{Si}_{2} \mathrm{O} / \mathrm{Na}_{2} \mathrm{O}$ ratio, the strength also increases.

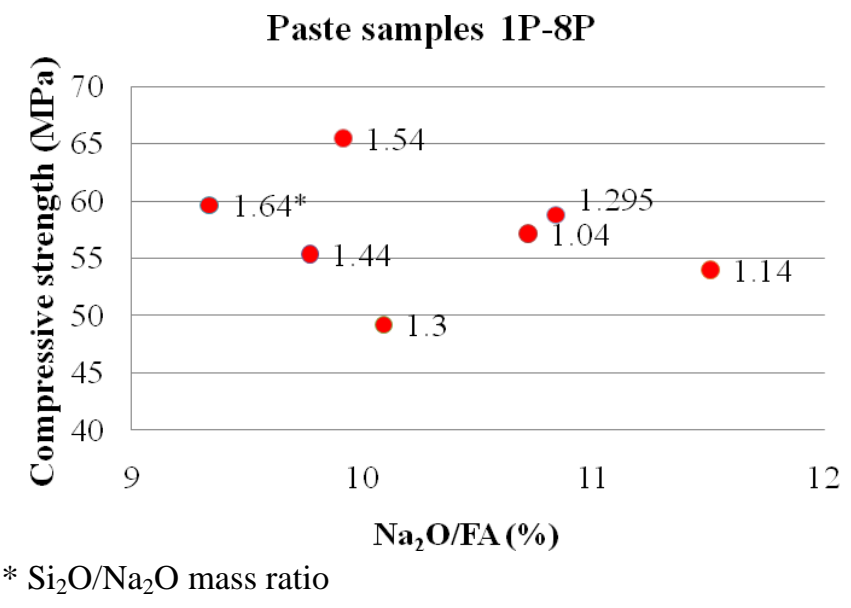

Fig. 4: Compressive strength of AAFAP samples 1P-8P depending on the percentage of $\mathrm{Na}_{2} \mathrm{O} / \mathrm{FA}$ 


\section{Paste samples 1P-8P}

\section{$\mathrm{SiO}_{2} / \mathrm{Na}_{2} \mathrm{O}$}

$* \mathrm{Na}_{2} \mathrm{O} / \mathrm{FA}$ percentages

Fig. 5: Compressive strength of AAFAP samples 1P-8P depending on the $\mathrm{Si}_{2} \mathrm{O} / \mathrm{Na}_{2} \mathrm{O}$ ratio

AAFAP mixtures were chosen in order to decide on what parameters are of biggest influence on the AAFAP compressive strength for this type of fly ash. Aside the compressive strength and workability, economical and ecological aspects are also analyzed.

Table 7 shows price in EUR per $\mathrm{m}^{3}$ of AAFAP 1P-8P on Serbian market. The price of AAFAP compared to Portland cement paste is mostly dependent on the price of $\mathrm{NaOH}$. Lower price of AAFAP will be achieved with higher $\mathrm{Na}_{2} \mathrm{SiO}_{3}$ and lower $\mathrm{NaOH}$ content. Equivalent $\mathrm{CO}_{2}\left(\mathrm{CO}_{2, \text { eq }}\right)$ of AAFAP is evaluated using life-cycle assessment done by Habert [41]. Table 7 also shows equivalent $\mathrm{CO}_{2}\left(\mathrm{CO}_{2, \mathrm{eq}}\right)$ in $\mathrm{kg}$ per $\mathrm{m}^{3}$ for AAFAP (activator solution) and compressive strength of AAFAP samples.

Table 7: Price, $\mathrm{CO}_{2, \text { eq }}$ and compressive strength of binder phase in AAFAC

\begin{tabular}{|l|l|l|l|}
\hline & $\begin{array}{l}\text { Price } \\
\left(\mathbf{E U R} / \mathbf{m}^{\mathbf{3}}\right)\end{array}$ & $\begin{array}{l}\mathbf{C O}_{\mathbf{2}, \mathbf{e q}} \\
\left(\mathbf{k g} / \mathbf{m}^{\mathbf{3}}\right)\end{array}$ & $\mathbf{f}_{\mathbf{p}, \mathbf{c}}$ (MPa) \\
\hline $\mathbf{1 P}$ & 34 & 238.44 & 57.11 \\
\hline $\mathbf{2 P}$ & 32 & 250.16 & 49.22 \\
\hline $\mathbf{3 P}$ & 31 & 256.02 & 55.31 \\
\hline $\mathbf{4 P}$ & 30 & 264.01 & 59.69 \\
\hline $\mathbf{5 P}$ & 40 & 263.17 & - \\
\hline $\mathbf{6 P}$ & 36 & 266.64 & 53.91 \\
\hline $\mathbf{7 P}$ & 34 & 268.38 & 58.83 \\
\hline $\mathbf{8 P}$ & 31 & 270.75 & 65.42 \\
\hline
\end{tabular}

The cost of Portland cement for the concrete with equivalent strength $\left(350 \mathrm{~kg} / \mathrm{m}^{3}\right.$ of cement) is around $42 \mathrm{EUR} / \mathrm{m}^{3}$ and $\mathrm{CO}_{2, \text { eq }}$ is $295.40 \mathrm{~kg} / \mathrm{m}^{3}$, which is just a slightly higher than equivalent $\mathrm{CO}_{2}$ of AAFAP. However, $\mathrm{CO}_{2 \text {,eq }}$ is increased with the increase of $\mathrm{Na}_{2} \mathrm{SiO}_{3}$ in the activator solution.

Having all this in mind, activator solution with $10 \mathrm{M} \mathrm{NaOH}$ and $\mathrm{Na}_{2} \mathrm{SiO}_{3} / \mathrm{NaOH}=10$ (paste $4 \mathrm{P}$ ) was chosen for AAFAC mixtures. Since the slump of concrete directly depends on the total water content, in order to determine the influence of additional water (aside from the water in activator solution) on the compressive strength of AAFAC, four mixtures were made - samples $1 \mathrm{C}-4 \mathrm{C}$.

Workability of AAFAC samples was measured with standard Abrams cone slump test. The results (Table 6) show that with the increase of water content in concrete mixture, the slump increases linearly (Figure 6).

For AAFAC samples $1 \mathrm{C}$ to $4 \mathrm{C}$, the slump was increased from $18.3 \mathrm{~cm}$ to $28.0 \mathrm{~cm}$ with the increase of water from 28 to $40 \mathrm{~kg} / \mathrm{m}^{3}$ of concrete mixture. Comparing results from slump test of mixtures $1 \mathrm{C}$ and $5 \mathrm{C}$, it can be concluded that slump decreases with the increase of molarity of $\mathrm{NaOH}$, same like in AAFAP.

Compressive strength of AAFAC mixtures were evaluated using $100 \times 100 \mathrm{~mm}$ cubes, 48 hours after mixing. Results are shown in Figure 7 and Table 6. Results show that compressive strength decreases with the increase of water in the mixture. The role of water in geopolymerization reaction of AAFAC is not fully confirmed and explained.

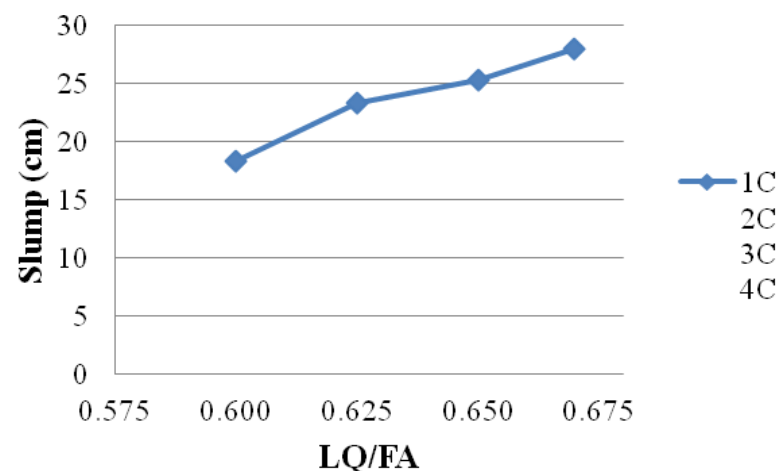

Fig. 6: Slump of AAFAC samples 1C, 2C, 3C and 4C depending on additional water content in concrete mixture

Results obtained by this research are consistent with other results from literature. It has been reported that the addition of extra water in the alkali activated system decreases the $\mathrm{pH}$ in the activator, reducing the dissolution rate of fly ash [42]. Hardjito and Rangan [36] showed that the compressive strength constantly decreased with higher water content.

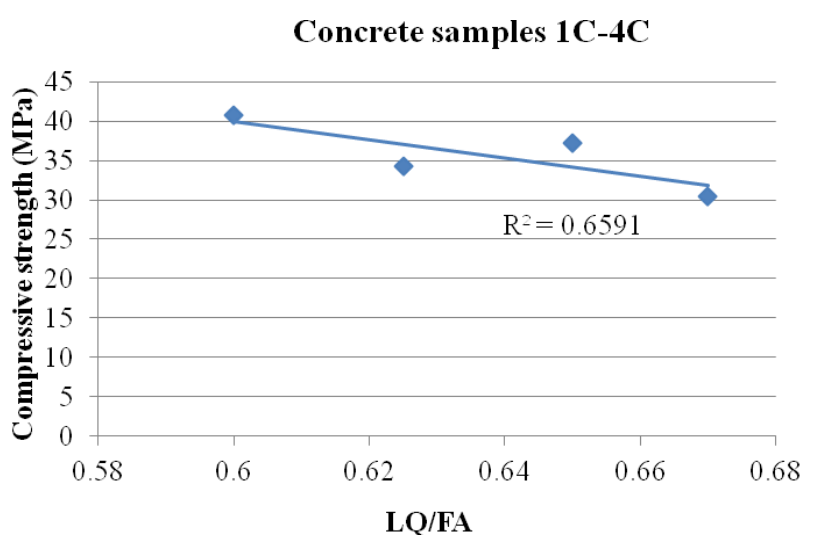

Fig. 7: Compressive strength of AAFAC samples $1 \mathrm{C}-4 \mathrm{C}$ depending of LQ/FA ratio 
In order to determine the influence of $\mathrm{NaOH}$ molarity on the AAFAC compressive strength, mixture $5 \mathrm{C}$ was prepared with $16 \mathrm{M} \mathrm{NaOH}$. Compressive strength of this mixture was $7 \%$ higher compared to $1 \mathrm{C}$ mixture compressive strength. The conclusion was consistent with conclusion made for AAFAP: increase in molarity increases the compressive strength. Mixture $6 \mathrm{C}$ with $11.51 \%$ of $\mathrm{Na}_{2} \mathrm{O} / \mathrm{FA}$ and $\mathrm{Si}_{2} \mathrm{O} / \mathrm{Na}_{2} \mathrm{O}=1.14$ was prepared to confirm that higher $\mathrm{Na}_{2} \mathrm{O} / \mathrm{FA}$ with significantly lower $\mathrm{Si}_{2} \mathrm{O} / \mathrm{Na}_{2} \mathrm{O}$ ratio results in strength decrease. Compressive strength of mixture $6 \mathrm{C}$ was $16.7 \%$ lower than mixture $5 \mathrm{C}$ with $9.92 \%$ of $\mathrm{Na}_{2} \mathrm{O} / \mathrm{FA}$ and $\mathrm{Si}_{2} \mathrm{O} / \mathrm{Na}_{2} \mathrm{O}=1.54$.

\section{CONCLUSIONS}

Based on the experimental work reported in this study, the following conclusions are drawn:

- Minimum content of alkali activator (sodium hydroxide and sodium silicate) needed for the preparation of AAFAC with fly ash from power plant "Nikola Tesla B" (Obrenovac, Serbia) was $60 \%$ of FA mass

- $\quad$ This AAFAC has slump between $13 \mathrm{~cm}$ and $27 \mathrm{~cm}$ and, if cured at $80{ }^{\circ} \mathrm{C}$ for 6 hours, compressive strength between $30 \mathrm{MPa}$ and $44 \mathrm{MPa}$, depending on the total liquid content and activator type

- Higher concentration (in terms of molar) of sodium hydroxide solution and higher sodium silicate-tosodium hydroxide ratio by mass results in higher compressive strength of AAFAC

- Water content influences the workability and compressive strength of AAFAC and in order to achieve high compressive strengths, new superplasticiser admixtures stable at high $\mathrm{pH}$ levels must be developed

- To date, the reaction mechanism of geopolymerisation is still not clear. Further research is needed in order to understand the influence of chemical composition and particle size distribution of fly ash and the influence of $\mathrm{Na}_{2} \mathrm{O}, \mathrm{SiO}_{2}$ and water content on the physical and mechanical characteristics of fresh and hardened AAFAC

- Large database should be built on the engineering properties of various AAFAC mixtures using fly ash from different sources

\section{ACKNOWLEDGEMENTS}

The work reported in this study is a part of the investigation within the Research Project TR36017: 'Utilization of byproducts and recycled waste materials in concrete composites in the scope of sustainable construction development in Serbia: investigation and environmental assessment of possible applications', supported by the Ministry for Education, Science and Technology, Republic of Serbia. This support is gratefully acknowledged.

\section{REFERENCES}

[1]. Coal Ash Facts, http://www.coalashfacts.org, accessed 17.06.2013.

[2]. Malhotra V.M., "High performance high-volume fly ash concrete for sustainable development", International Workshop on Sustainable Development and Concrete Technology, Beijing, May 20-21 2004, p. 3-14, 2004.

[3]. Electric Power Industry of Serbia (EPS), Technical Report

2010 ,

(http://www.eps.rs/Eng/Tehnicki\%20Izvestaji//TEH_Godisn jak2010_en_web.pdf), accessed 16.06.2013.

[4]. Privredna komora Srbije, "Upotreba elektrofilterskog pepela i sljake proizvedenih iz termoenergetskih izvora", 2011.

[5]. Chen, I.A., and M.C.G. Juenger. Incorporation of Waste Materials into Portland Cement Clinker Synthesized from Natural Raw Materials. Journal of Materials Science, 2009, 44, no. 10:2617-2627.

[6]. Greer, W. L., G. J. Hawkins, and T. B. Carter. Air Emissions and Control Measures. Chap. 6.1 in Innovations in Portland Cement Manufacturing. Skokie, 2004, Illinois: Portland Cement Association.

[7]. Mehta, P. K., "Reducing the Environmental Impact of Concrete", Concrete International, V. 23, No. 10, Oct. 2001, pp. 61-66.

[8]. Provis JL, van Deventer JSJ, "Alkali-activated materials: State-of-the-Art Report”, RILEM TC 224-AAM. Springer/RILEM, Berlin, 2013.

[9]. Petermann, Jeffrey C.; Saeed, Athar; Hammond, Michael I, "Alkali-activated geopolymers: a literature review”, Applied Research Associates, Panama City, 2010.

[10]. Fernandez-Jimenez A., Garcia-Lodeiro I., Palomo

A., "Durability of Alkali-Activated Fly Ash Cementitious Materials", J. Mater. Sci., 42-3055-3065, 2007.

[11]. Davidovits J., "The need to create a new technical language for the transfer of basic scientific information", In: Gibb, J.M., Nicolay, D. (eds.) Transfer and Exploitation of Scientific and Technical Information, EUR 7716, pp. 316320. Commission of the European Communities, Luxembourg, 1982.

[12]. Davidovits J, "Geopolymer chemistry and applications. Institut Ge opolymere, Saint-Quentin”, 2008.

[13]. Kuhl H, Slag cement and process of making the same. US Patent 900,939, 1908.

[14]. Purdon AO, The action of alkalis on blast-furnace slag. J Soc Chem Ind 59:191-202, 1940.

[15]. Vanooteghem M, Duurzaamheid van beton met alkaligeactiveerde slak uit de jaren 50-Het Purdocement. M.Ing. Thesis, Universiteit Gent, 2011.

[16]. Glukhovsky VD, Gruntosilikaty (soil silicates). Gosstroyizdat, Kiev, 1959.

[17]. Shi C, Krivenko PV, Roy DM (2006) Alkali-activated cements and concretes. Taylor \& Francis, Abingdon

[18]. van Deventer JSJ, Provis JL, Duxson P, Technical and commercial progress in the adoption of geopolymer cement. Miner Eng 29:89-104, 2012.

[19]. ASTM C618-12a: Standard Specification for Coal Fly Ash and Raw or Calcined Natural Pozzolan for Use in Concrete, ASTM International, West Conshohocken, 2012. 
[20]. Palomo, A., Grutzeck, M., et al. "Alkali-activated fly ashes: a cement for the future." Cement and Concrete Research 29(8): 1323-1329, 1999.

[21]. Davidovits, J. "Chemistry of geopolymeric systems, terminology." Geopolymere 99: 9-39, 1999.

[22]. Xu, H. and Van Deventer, J., "The geopolymerisation of alumino-silicate minerals." International Journal of Mineral Processing 59(3): 247-266, 2000.

[23]. Palomo, A., Grutzeck, M., et al. "Alkali-activated fly ashes: a cement for the future." Cement and Concrete Research 29(8): 1323-1329, 1999.

[24]. Fernandez-Jimenez A., Palomo A., Criado M., Microstructure development of alkali-activated fly ash cement: a descriptive model, Cem. Concr. Res. 35: 12041209, 2005.

[25]. Criado M., Palomo A., Fernandez-Jimenez A., Alkali activation of fly ashes. Part 1: Effect of curing conditions on the carbonation of the reaction products, Fuel, 84: 20482054, 2005.

[26]. Kovalchuk G., Fernandez-Jimenez A., Palomo A., Alkali-activated fly ash: Effect of thermal curing conditions on mechanical and microstructural development - Part II, Fuel, 86: 315-322, 2007.

[27]. Criado M., Fernandez Jimenez A., Palomo A., Alkali activation of fly ash. Part III: Effect of curing conditions on reaction and its graphical description, Fuel, 89: 3185-319, 2010.

[28]. Palomo A., Grutzeck M.W., Blanco M.T., Alkali activated fly ashes: a cement for the future, Cem. Concr. Res. 29: 1323-1329, 1999.

[29]. Malolepszy, J., Deja, J. and Brylicki, W.: Industrial application of slag alkaline concretes. In: Krivlenko, P.V., (ed) Proceedings of the First International Conference on Alkaline Cements and Concretes, Kiev, Ukraine. Vol. 2, pp. 989-1001. VIPOL Stock Company, 1994.

[30]. van Deventer, J.S.J., Provis, J.L., Feng. D. and Duxson, P.: The role of mineral processing in the development of cement with low carbon emissions. In: XXV International Mineral Processing Congress (IMPC), Brisbane, Australia. pp. 2771-2781. AusIMM, 2010.

[31]. Ahmed, Y.H. and Buenfled, N.R.: An investigation of ground granulated blast furnace slag as a toxic waste solidification/stabilization reagent. Environ. Eng. Sci. 14(2), 113-132, 1997.

[32]. Fernandez-Jiménez, A., Palomo, A., LopezHombrados, C. (2006). "Engineering Properties of AlkaliActivated Fly Ash Concrete.” ACI Materials Journal.: 106112, 2006.

[33]. Ravikumar, D., Peethamparan, S., and Neithalath, N. "Structure and Stregnth of $\mathrm{NaOH}$ Activated." Cement and Concrete Composites 32 (2010): 399-410.

[34]. Djwantoro Hardjito, PhD Thesis: Studies on Fly AshBased Geopolymer Concrete, 2005.

[35]. Fernandez-Jimenez, A., Puertas, F., "The Alkali-Silica Reaction in Alkali-Activated Granulated Slag Mortars with Reactive Aggregate", Cement and Concrete Research 32, pp. 1019-1024, 2002.

[36]. Hardjito, D. and Rangan, B.V. . "Development and properties of low-calcium fly ash based geopolymer concrete." Research report GC, 2005.
[37]. Vijaya Rangan, B., "Fly Ash-Based Geopolymer Concrete", available at: http://www.yourbuilding.org/display/yb/Fly+AshBased+Ge opolymer+Concrete

[38]. Fernandez-Jimenez, A., Monzo, M., Vicent, M., Barba A., Palomo, A., "Alkaline Activation of Metakaolin-Fly Ash Mixtures: Obtain of Zeoceramics and Zeocements", Microporous and Mesoporous Materials 108, pp. 41-49, 2008.

[39]. Duxson P, Fernandez-Jimenez A, Provis JL, Lukey GC, Palomo A, van Deventer JSJ (2007) "Geopolymer technology: the current state of the art". J Mater Sci 42(9):2917-2933, 2007.

[40]. SRPS EN 196- 1:2008, SRPS EN196-1: Methods of testing cement - Part 1: Determination of strength, 2008.

[41]. G. Habert, J.B. d'Espinose de Lacaillerie, N. Roussel. "An environmental evaluation of geopolymer based concrete production: reviewing current research trends", Journal of Cleaner Production, 19: 1229-1238, 2011.

[42]. Duxson, P., Provis, J.L., et al. "The role of inorganic polymer technology in the development of 'green concrete'." Cement and Concrete Research 37(12): 1590-1597, 2007.

\section{BIOGRAPHIES}

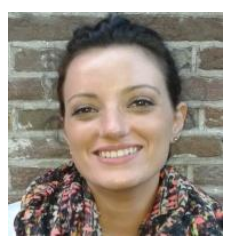

Jelena Dragas is currently employed as a teaching and research assistant at FCE Belgrade, Chair for Materials and Structures, and attending PhD studies at the same faculty. Her research and study fields are concrete structures, new sustainable concrete materials and recycled concrete.

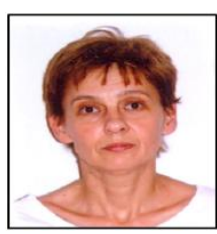

Prof. Dr. Snezana Marinković is a professor at the Chair for Materials and Structures, FCE Belgrade. During last five years, main research interest has been focused on the eco efficient design and construction of concrete structures. She worked particularly in the area of Life Cycle Assessment of concrete structures.

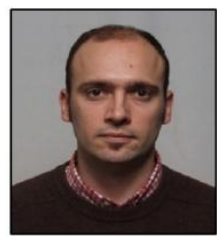

Dr. Ivan Ignjatovic is currently employed as an assistant professor at FCE Belgrade, Chair for Materials and Structures. Reuse of concrete demolition waste in the production of structural concrete and behavior of reinforced concrete elements made of recycled aggregate concrete have been the main research topics in the last five years.

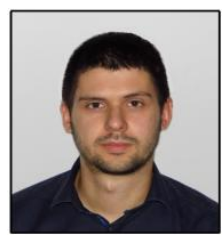

Nikola Tosic is a young researcher, currently employed as a teaching assistant at FCE Belgrade, Chair for Materials and Structures, and attending $\mathrm{PhD}$ studies at the same faculty. His research and study fields are reinforced and prestressed concrete structures. 